\title{
НОВЫЕ АНТИБАКТЕРИАЛЬНЫЕ КАТИОННЫЕ АМФИФИЛЫ
}

\author{
С.М. Филатова, В.О. Овсянников, У.А. Буданова, Ю.Л. Себякин
}

МИРЭА - Российский технологический университет, 119571, Россия, г. Москва, пр.Вернадского, 86.

DOI: 10.19163/MedChemRussia2021-2021-508

E-mail: c-221@yandex.ru

Перспективным классом новых антибактериальных агентов являются катионные пептидомиметики, обладающие значительнойантимикробнойактивностьюпо сравнению с известными антибиотиками [1].Резистентность бактерий к таким молекуламвозникает значительно медленнее чем к традиционным антибиотикам, так как мишенью их действия является бактериальная мембрана [2]. На основании литературных данных для синтеза были выбраны соединения с величинойгидрофильно-липофильного баланса (ГЛБ) в диапазоне 4-6 [3].

Разработанная схема синтеза позволяет получать соединения с заданным набором свойств благодаря тонкой настройке структуры пептидомиметиков на основе диэтаноламина в гидрофобном блоке и остатков L-лизина, L-орнитина, глицина, L-аланина, L-фенилаланина в полярном блоке. Сложноэфирные связи в гидрофобной области и спейсерная амидная связь должны увеличивать биодоступность и снижать цитотоксичность молекулы по отношению к клеткам млекопитающих.

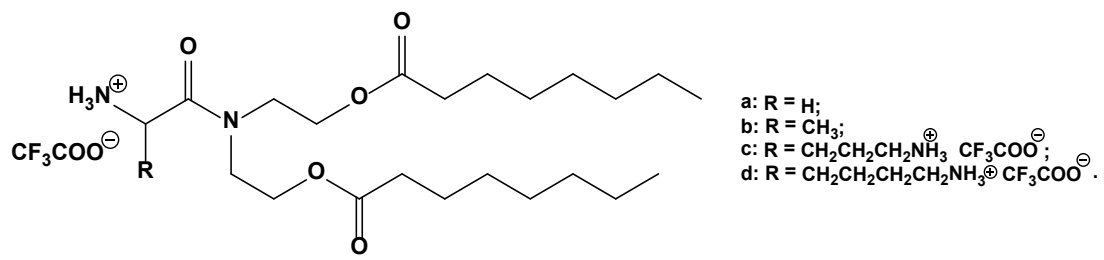

Конечные соединения получены в количествах, достаточных для проведения микробиологических исследований. По результатам предварительных тестовамфифилы проявляют активность против S.subtilis и E.coli в диапазоне МИК 1-100 мкг/мл.

Работа поддержана Российским Фондом Фундаментальных исследований, грант РФФИ № 20-04-00672

\section{Литература}

1. Zhang, E., Bai, P.-Y., Cui, D.-Y., Chu, W.-C., Hua, Y.-G., Liu, Q., and Liu, H.-M., European Journal of Medicinal Chemistry. 2018, 143, 1489-1509.

2. K. Matsuzaki, Biochim. Biophys. Acta. 1999, 1462, 1-10.

3. Filatova, S. M., Denieva, Z. G., Budanova, U. A. and Sebyakin, Y. L., Moscow University Chemistry Bulletin. 2020, 75(6), 320-327. 